\title{
鉄骨高層建物の上下方向振動性 VERTICAL DYNAMIC 状に関する検討 \\ CHARACTERISTICS OF A HIGH-RISE STEEL BUILDING
}

\section{護 雅史—*1 \\ 神原 浩—*2}

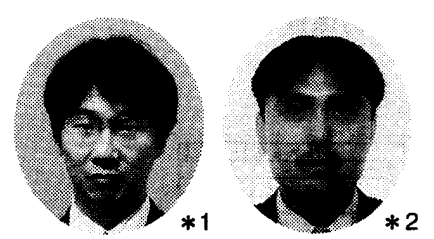

Masafumi MORI

Hiroshi KAMBARA
We measured micro-tremors of a high-rise steel building to research detailed vertical dynamic characteristics. In this paper, we make clear that there are some vertical modal shapes: axial extension mode of column, beam vibration mode, those coupled of each other, in a narrow frequency band. Furthermore, we verify our results by modeling comparisons of seismic motion results recorded in this building and eigenvalues by a 3-dimensional frame model. We conclude that it is necessary to propose a new analysis model to simulate vertical responses of buildings accurately.
キーワード :

上下方向の振動性状, 常時徽勤計測, 3次元立体解析, 鉄骨高隔建物
Keywords

Vertical dynamic characteristics, Microtremor, 3-D frame analysis, High-rise steel building

\section{1.はじめに}

近年、建物の高層化、大スパン化に伴って、曲げ変形に伴う柱の変 動軸力の検討や居住性に対する床の振動レベルの検討など、建物の上 下方向応答性状が設計上重要な問題のひとつとなってきている。ま た、多くの建物に甚大な被害を与えた1995年兵庫県南部地震では、直 下型地震の上下動特性と建物被害との関係が論じられるなど、研究的 にも建物の上下方向の応答性状に関する問題意識は高まりつつある。 建物の応答解析を行う際には、まず、その振動性状を十分に検討し た上で、実現象をうまくシミュレートできるモデルを作成することが 重要である。水平方向の場合、微動計測記録や地震観測記録を用いた 分析が以前から行われており文は:[5],[10].[12] その振動性状はかなり明確 にされてきている。また、このような実記録データの萻積を背景とし て、一本棒の多犋点系モデルは、水平方向の振動性状を十分に表現で きる簡便な解析モデルのひとつとして、設計に研究に幅広く利用され てきている。一方、上下方向の場合を見てみると、水平方向に比べて 微動計測記録等の分析事例等が少なく[11.61、建物全体としての上下方 向の振動性状は十分に把握されていないのが実状である。例えば、上 下振動の固有振動モードは一般的に柱の軸伸縮モードと床振動モード として現れる梁の曲げモードに大別されるが、それらの卓越振動数 や、而者の連成や水平方向との連成の有無は、建物の構造種別や構造 形式、架構形式等によって異なるはずである。こうした中で、上下方 向の振動解析においては、水平方向にある一本棒の多質点系モデルの ような沉用的な簡易解析モデルがないため、個々人が問題に応じて工

*1 清水建設(侏和泉研究室 研究員

（祼 100 千代田区内幸町 2-2-2）

*2 清水建設(俳和泉研究室 研究員
学的判断を入れながら独自の解析モデルを作成している場合が多い。 これは、解析对象が同じであっても、用いた解析モデルによって結果 が大きく異なる危険性が考えられるため、今後上下応答に関する検討 の必要性が増し、多くの研究者や設計者らが解析を行う場合にはあま り望ましいことではない。従って、建物全体としての上下方向の振動 性状をうまく表現できる汎用的な籣易解析モデルが必要である。ま た、そのためには微動計測等による上下方向の振動性状に関するデー 夕の蓄積が不可欠である。

このような観点から、上下方向の振動性状に関するデータの蓄積 と、上下応答解析用簡易モデルの開発を目的として、某鉄骨高層建物 において、上下方向を中心とした常時微動の水平・上下同時計測を 行った。本論では、上下用簡易解析モデルの開発の前段階として、こ の微動計测結果に基ついいて鉄骨高層建物の上下方向の振動特性（振動 モードとその卓越振動数）についての詳細な検討を行う。さらに、そ の検討結果を検証するために、同建物で得られている地震観測記録を 用いた検討と 3 次元立体解析モテルによる検討も併せて行う。

\section{2. 建物概要・常時微動計測概要・対象地踶}

\section{1 建物概要}

対象建物は、東京都港区に 1991 年に端工した地上 24 階、地下 2 階 のセンターコア形式をとる鉄骨造事務所建物である (図1参照)。同建 物は $\mathrm{S}$ 棟と $\mathrm{N}$ 棟からなるッインタワーで、地下部分は一体化されてい る。基礎構造は上総層群を支持基盤とした直接基礎としている。ま

\footnotetext{
*1 Researcher, Izumi Research Institute, Shimizu Corporation

*2 Researcher, Izumi Research Institute, Shimizu Corporation
} 


\section{表 1 検討に用いた地要の諸元}

\begin{tabular}{|c|c|c|c|c|c|c|}
\hline & & & $\begin{array}{c}\text { NO.1 } \\
1992 \text { Tokyo Bay }\end{array}$ & $\begin{array}{c}\text { NO.2 } \\
1993 \text { Off Kushiro }\end{array}$ & $\begin{array}{c}\text { NO.3 } \\
\text { South-West Ibaraki }\end{array}$ & $\begin{array}{c}\text { NO.4 } \\
\text { Off Tokai-do } \\
\end{array}$ \\
\hline \multicolumn{3}{|l|}{ Date } & 2 Feb. 1992 & 15 Jan. 1993 & 21 May. 1993 & 12 Oct. 1993 \\
\hline \multicolumn{3}{|l|}{ Hypocenter } & $13948 \mathrm{E} 3512 \mathrm{~N}$ & 144 23E $4251 \mathrm{~N}$ & $13954 \mathrm{E} 3603 \mathrm{~N}$ & $13806 \mathrm{E} 3206 \mathrm{~N}$ \\
\hline \multicolumn{3}{|l|}{ Magnitude } & 5.7 & 7.8 & 5.4 & 7.1 \\
\hline \multicolumn{3}{|l|}{ Depth(km) } & 90 & 107 & 61 & 390 \\
\hline \multicolumn{3}{|c|}{ Epicentral Distance $(\mathbf{k m})$} & 40 & 893 & 46 & 422 \\
\hline \multicolumn{3}{|c|}{ Seismic Intensity in Tokyo } & III & III & IV & IV \\
\hline \multirow{6}{*}{$\begin{array}{c}\text { Max Acc. } \\
(\mathrm{cm} / \mathrm{sec} / \mathrm{sec})\end{array}$} & \multirow{2}{*}{ NS } & $\mathbf{R F}$ & 35 & 10 & 14 & 21 \\
\hline & & IF & 38 & 4 & 9 & 16 \\
\hline & \multirow[b]{2}{*}{ EW } & RF & 82 & 10 & 12 & 16 \\
\hline & & IF & 69 & 4 & 9 & 9 \\
\hline & \multirow{2}{*}{ UD } & $\mathbf{R F}$ & 45 & 10 & 24 & 17 \\
\hline & & $1 \mathrm{~F}$ & 27 & 3 & 10 & 5 \\
\hline
\end{tabular}

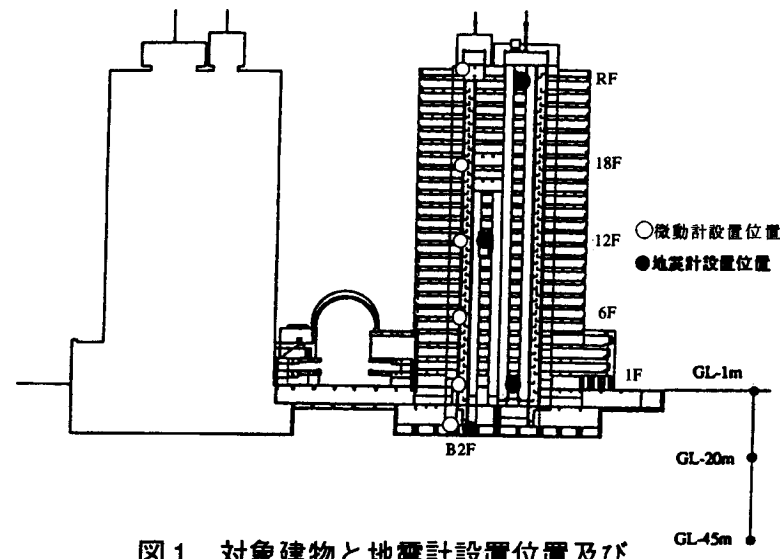

図 1 対象建物と地霆計設置位置及び 微動計設置位置（ケース4）

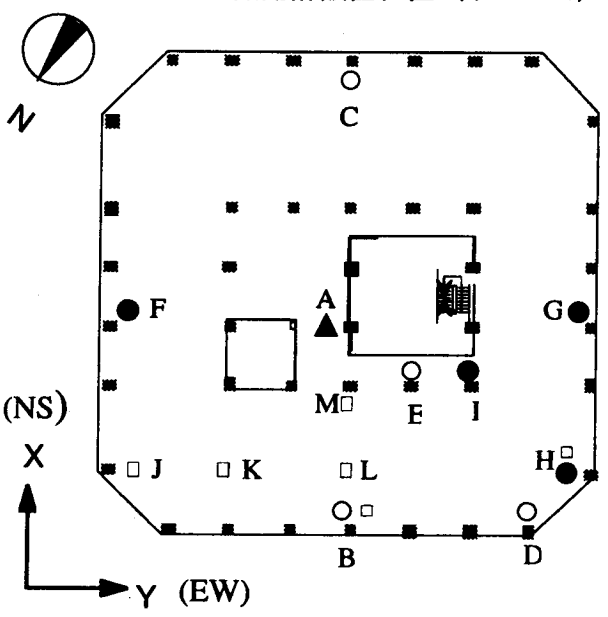

図 2 計測点の概略図（屋上㳻）

た、 $\mathrm{S}$ 棟の一方向（X方向）にのみ粘弾性ダンパーを用いた制振装置 が設置されている。

\section{2 常時微動計測概要}

今回の計測は、次に示す 4 ケースについて行った。

(1) ケース 1:Y方向柱（外柱と中柱）の多点同時計測

(2) ケース $2: X$ 方向柱（外柱と中柱）の多点同時計測

（3）ケース $3:$ 屋上階床の多点同時計測

（4）ケース 4: 階段室内（図 1 参照）の多点同時計測

図2にヶース 1 ３の屋上階の計測点を示す。なお、ケース 1、2で は建物内での増幅特性を調べるために、1階にも微動計を設置して同 時計測を行った。また、水平成分との連成の有無を確認するために、 全ての計測点において水平・上下同時計測を行っている。1ケースの 計測時間は約 22 分とした。図3に計測システムを示す。本計測システ

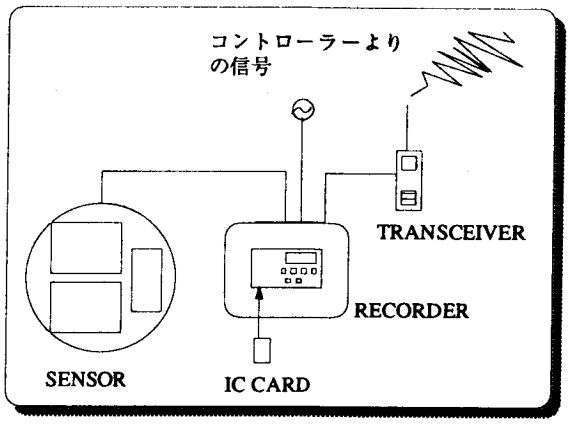

図3 計測システムの概略図
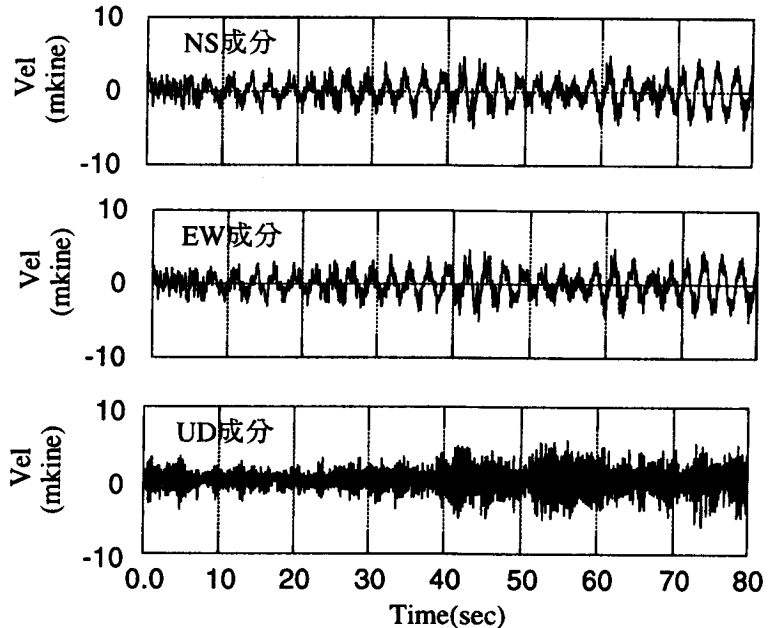

図4計測された常時微動波形（A 点）

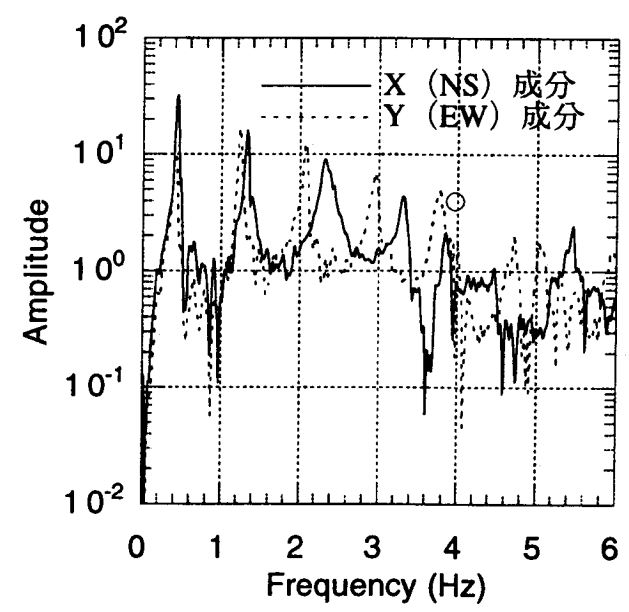

図 5 A 点の 1 階に対する伝達関数（水平 2 成分）

ムでは各計測地点にセンサー 3 台（水平 2+上下）とレコーダー1台、 さらにトランシーバー1台をセットする。センサーは東京測振製VSE11/12を使用している。計測は別途設置するコントローラーからの無 線信号によって同時にトリガーし同時計測され、ICカードに記録され る。ケース4では、無線を用いる本システムが階段室内でも動作する かどうかの確認も併せて行っている。

\section{3 対象地霞}

同建物では竣工当初から地震観測（図 1 参照）が実施されており、 現在までに数十の地震記録が観測されている。これらの地震記録の 内、東京で震度III以上を記録した4つの地震を本論では用いることに する。各地震の諸元を表 1 に示す。これらの地震の最大応答加速度の 
表 2 微動計測結果より得られた固有振動数（水平方向）

\begin{tabular}{|c|c|c|c|c|c|}
\hline & \multicolumn{2}{|c|}{$X$ (NS) 並進 } & & \multicolumn{2}{|c|}{ Y (EW) 並進 } \\
\hline & $\begin{array}{c}\text { 固有振動数 } \\
(\mathrm{Hz})\end{array}$ & $\begin{array}{c}\text { 固有周期 } \\
\text { (sec) }\end{array}$ & & $\begin{array}{c}\text { 固有振動数 } \\
(\mathrm{Hz})\end{array}$ & $\begin{array}{c}\text { 固有周期 } \\
(\mathrm{sec})\end{array}$ \\
\hline (1) & 0.43 & 2.3 & (1) & 0.41 & 2.4 \\
\hline (2) & 1.3 & 0.77 & (2) & 1.2 & 0.83 \\
\hline (3) & 2.3 & 0.43 & (3) & 2.1 & 0.48 \\
\hline (4) & 3.3 & 0.30 & (4) & 3.0 & 0.33 \\
\hline (5) & & & (5) & 3.7 & 0.27 \\
\hline
\end{tabular}

表 3 微動計測結果より得られた固有振動数（上下方向）

\begin{tabular}{|c|c|c|c|}
\hline & $\begin{array}{c}\text { 固有振動数 } \\
(\mathrm{Hz})\end{array}$ & $\begin{array}{c}\text { 固有周期 } \\
(\mathrm{sec})\end{array}$ & モード種別 \\
\hline (1) & 3.5 & 0.29 & 一様軸伸縮（全体） \\
\hline (2) & 3.7 & 0.27 & X軸巡対称軸伸縮（全体）+Y方向並進+梁の曲げ \\
\hline (3) & 3.9 & 0.26 & Y軸逆对称軸伸編（全体）+梁の曲げ \\
\hline (4) & 4.6 & 0.22 & 一様軸伸縮（外周）+梁の曲げ \\
\hline (5) & 4.75 & 0.211 & 一様軸伸縮（コア） \\
\hline (6) & 4.8 & 0.208 & Y軸逆対称軸伸縮 (外周) +梁の曲け \\
\hline
\end{tabular}

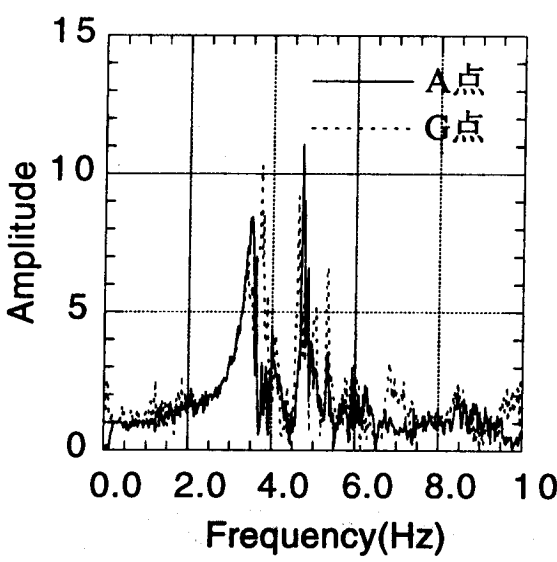

(a) ケース 1 (A 点、 $\mathrm{G}$ 点)

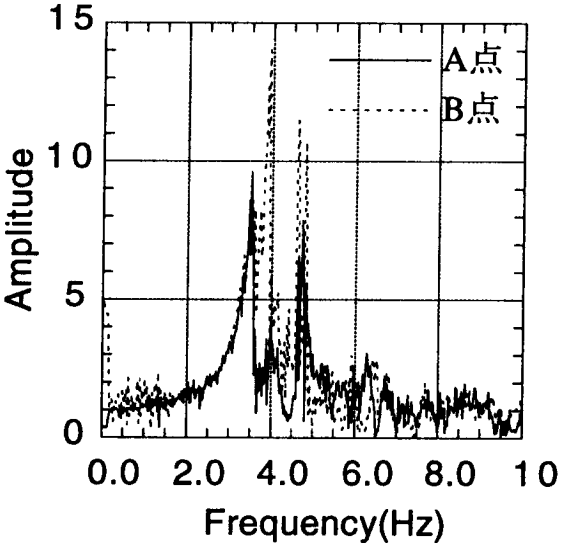

(b) ケース2 (A 点、B点)

図6 ケース1、2における A、B、G点の1階に対する伝達関数

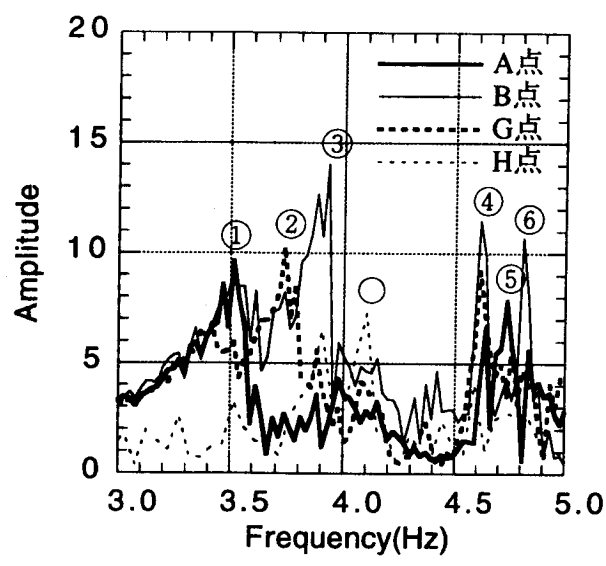

図 $7 A$ 点、B点、 $G$ 点、 $H$ 点の 1 階に対する伝達関数 $(3.0 \mathrm{~Hz} \sim 5.5 \mathrm{~Hz})$

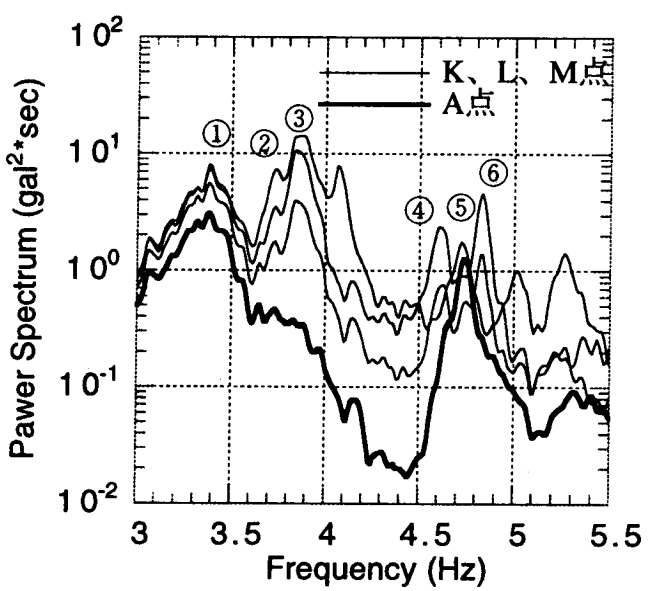

図8 ケース3における A、K、L、M点のパワースペクトル

1 階に対する屋上階の増幅率は、上下方向で $1.7 \sim 3.2$ 倍、水平方向で $0.9 \sim 2.6$ 倍であり、いずれも上下方向が水平方向を上回っている。

\section{3. 検討結果}

\section{1 微動計測結果に基つく分析}

計測は全て日中に行った。その間、天気は概ね晴れ、風速 $1.0 \mathrm{~m}$ 前 後あった。

図4にA点における代表的な常時微動波形（3成分）を示す。図 5 に $\mathrm{A}$ 点の水平 2 方向の 1 階に対する伝達関数を、表 2 に得られた水平 方向の固有振動数を示す。この結果は、同建物において過去に行われ た常時微動計測結果、及び起振機試験結果 ${ }^{[10]}$ と大凡一致していた。 従って、今回用いた微動計測システムで、これまでと同じような計測 結果が得られることがわかった。また、ケース4の計測によって、階
段室内でも無線による同時計測が可能であることも確認できた。

図6(a)、図6(b)はそれぞれ、ケース1、ケース2の建物コア部（計測

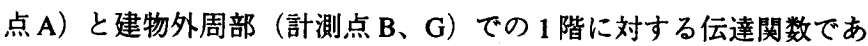
る。伝達関数は12波のアンサンブル平均を用いている。これらの図か ら、 $3.5 \mathrm{~Hz} \sim 4.0 \mathrm{~Hz}$ と $4.5 \mathrm{~Hz} \sim 5.0 \mathrm{~Hz}$ に複数のピークが近接して現れて おり、その数は建物コア部よりも建物外周部の方が多いことがわか る。これらは、上下方向の軸伸維モード、梁の曲げモード、两者の連 成、水平方向の振動モードとの連成等によって生じているものと考え られる。そこで、これらの振動数領域について詳細な検討を行うこと にする。

図7は、各計測点の 1 階に対する屋上階の伝達関数を $3.0 \mathrm{~Hz} \sim 5.0 \mathrm{~Hz}$ で拡大して示したものである。なお、図には H点の結果も併せて揭载 してある。また図8は、ケース 3 における A、K、L、M点の上下方向 のパワースペクトルである。ここで、図7、8で(1)の振動数に差が見ら れるのは、伝達関数（図 7) とパワースペクトル（図8）の違いであ る。ただし、この差が地盤の影響によるものかどうかは、今回の結果 からは判別できなかった。

まず図 7 を見ると、 $3.5 \mathrm{~Hz} \sim 4.0 \mathrm{~Hz}$ では、(1)約 $3.5 \mathrm{~Hz} 、$ (2)約 $3.7 \mathrm{~Hz}$ 、 (3)約 $3.9 \mathrm{~Hz}$ に顕著なピークがあり、(2)、(3)では外柱（それぞれ G 点、 B 点) の増幅が大きい。また、 $4.5 \mathrm{~Hz} \sim 5.0 \mathrm{~Hz} て ゙ は 、(4)$ 約 $4.6 \mathrm{~Hz}$ 、(5)約 $4.75 \mathrm{~Hz}$ 、6)約 $4.8 \mathrm{~Hz}$ に顕著なピークがあり、4.6Hzでは外柱（B点、G 点) が増幅、 $4.75 \mathrm{~Hz}$ では中柱（A 点）が増幅している。4.8Hzでは中 柱（A 点）と外柱（B 点）で増幅が大きい。次に図 8 を見ると、(1) と (5)以外ではA点でのパワーが他点に比べて小さくなっており、このこ とから、(1)と(5)以外では梁の曲げモードが明瞭に現れていると考えら れる。

以上の結果と、計測点間の上下成分の位相差や、水平成分との相関 


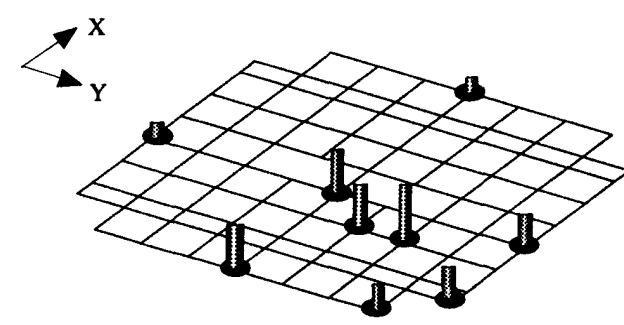

(1) $3.5 \mathrm{~Hz}$ （一様軸伸縮（全体)）

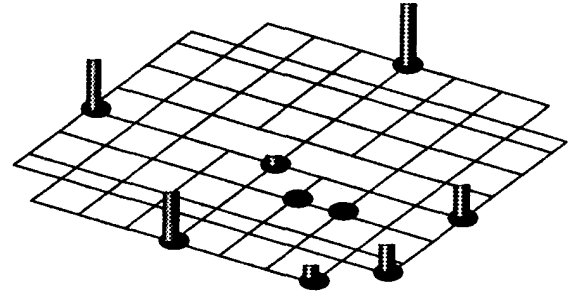

(4) $4.6 \mathrm{~Hz}$ (一様軸伸樎（外周）+梁の曲げ）

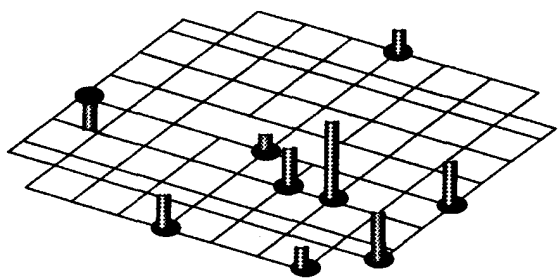

(2) $3.7 \mathrm{~Hz}$ (X轴逆対称軸伸樎（全体） $+Y$ 方向並進 5 次 + 梁の曲(f)

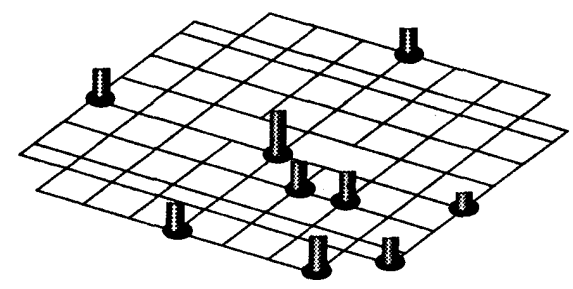

(5) $4.75 \mathrm{~Hz}$ (一様軸伸縮 (コア))

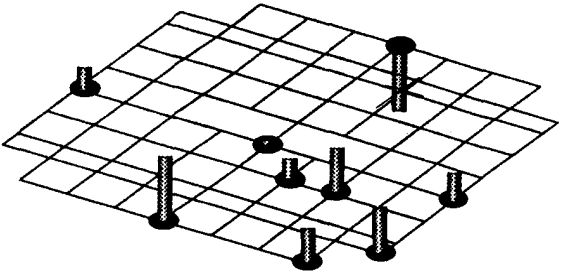

(3) $3.9 \mathrm{~Hz}$ （Y 軸逆対称軸伸樎（全体） + 梁の曲(f)

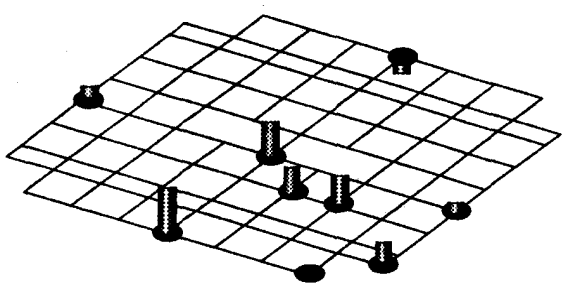

(6) $4.8 \mathrm{~Hz}+(Y$ 軸逆対称軸伸樎（外周） +梁の曲(f)

図 9 微動結果より伝達関数を用いて求められた上下方向の振動モード図

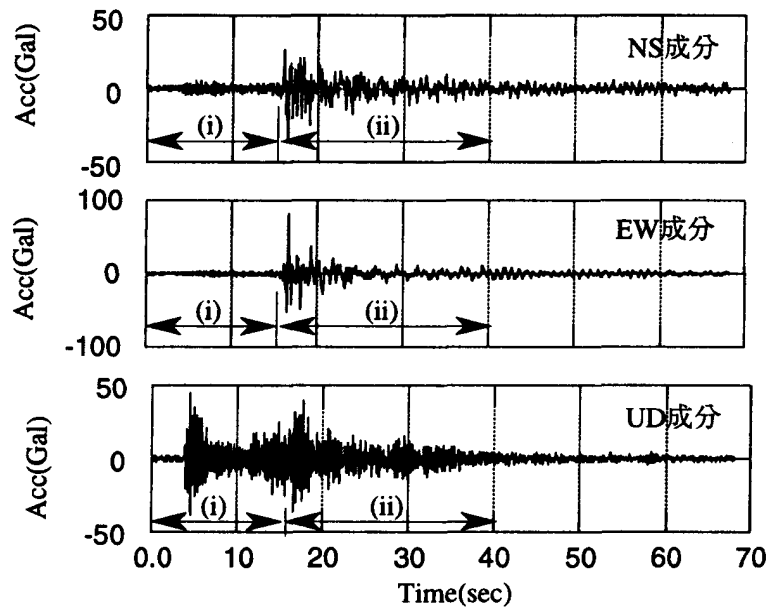

图 10 地霆観測記録波形（No.1）

性の有無等を考虑すると、これら6つのモードは、

(1) $3.5 \mathrm{~Hz}$ : 全体の一様軸伸維モード

(2) $3.7 \mathrm{~Hz}$ : 全体の $\mathrm{X}$ 軸逆対称軸伸縮モード+Y方向並進 5 次モード+梁 の曲げモード

(3) $3.9 \mathrm{~Hz}$ : 全体の Y 軸逆対称軸伸縮モード+梁の曲げモード

(4) $4.6 \mathrm{~Hz}$ : 外周部の一様軸伸縮モード+梁の曲げモード

(5) $4.75 \mathrm{~Hz}:$ :コア部の一様軸伸縮モード

(6) $4.8 \mathrm{~Hz}$ : 外周部の Y 軸逆対称軸伸縮モード+梁の曲げモード であると推定される。また、図 5 中の○印のピークの振動数と(3)の振 動数が一致していることと、水平方向の検討結果から、図 5 中の○印 のピークは上下方向の(3の振動モードによって励起されるものである ことがわかった。各計測点の伝達関数から求めた屋上階の振動モード を図9に、また同定結果を表 3 に示す。

\section{2 地震観測記録による分析}

次に地震観測記録を用いた場合の分析結果について示す。解析は先 に示した 4 地震で行ったが、紙面の都合上ここでは、NO.1 地震につい ての結果のみ示す。図 10は No.1 地震の屋上階での観測記録波形であ

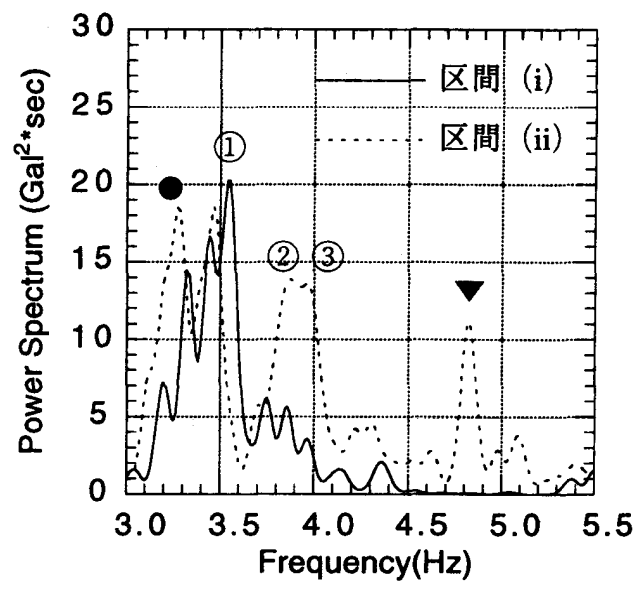

図11 屋上階のパワースペクトル $(3.0 \mathrm{~Hz} \sim 5.0 \mathrm{~Hz})$

る。この地震は図からも明らかなように、(i)初動部と(ii)主要動部とに 明瞭に区別できる。従って、初動部のみのスペクトルは上下並進モー ドが卓越し、主要動部のみのスペクトルでは逆対称軸伸縮モードが卓 越することが予想される。図11は、それぞれの区間で切り出した波か ら求めた屋上階のパワースペクトルである。眓中の実線が(i)初動部、 点線が(ii)主要動部の結果である。この図から初動部では約 $3.5 \mathrm{~Hz}$ に(1) に対応するピークが、主要動部ではこの他に約 $3.8 \mathrm{~Hz} 、$ 約 $3.9 \mathrm{~Hz}$ にそ れぞれ(2)、(3)に対応するピークが現れている。これらの結果は、微動 計測結果と良く一致している。また、黒丸で示したピーク（約 $3.3 \mathrm{~Hz} ）$ は微動計測結果では見られなかったが、 $\mathrm{X}$ 方向の4次の並進モードに よってY軸逆対称軸伸縮モードが励起されたためであろう。一方、 印のピーク（約 $4.8 \mathrm{~Hz}$ ）は図 5 を参照すると、Y方向の並進モードに よって励起されたピークであると考えられる。

\section{3 立体解析モデルによる検討}

微動計測、及び、地震観測記録から同定された振動性状を確認する ために 3 次元立体解析モデルによる固有值解析を行った。解析モデル は設計図書等を参考に作成している。架構は柱と大梁、及び小梁を梁 


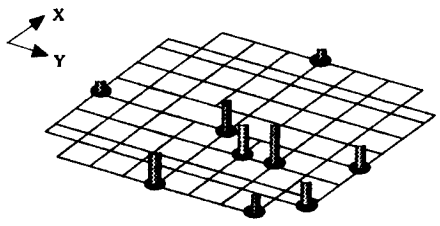

(1) $3.5 \mathrm{~Hz}$

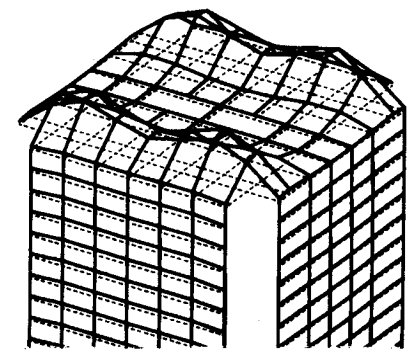

(1) $3.60 \mathrm{~Hz}$

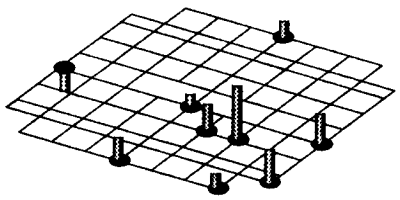

(2) $3.7 \mathrm{~Hz}$

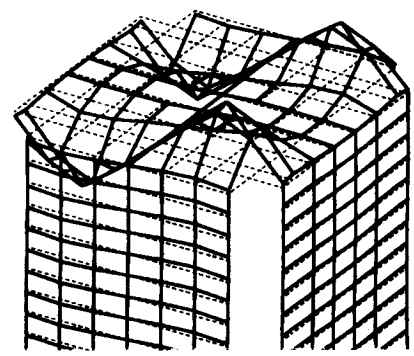

(2) $3.69 \mathrm{~Hz}$

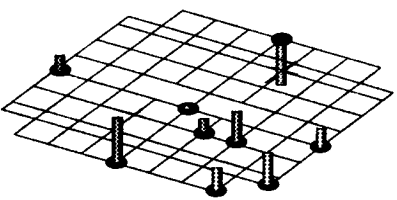

(3) $3.9 \mathrm{~Hz}$

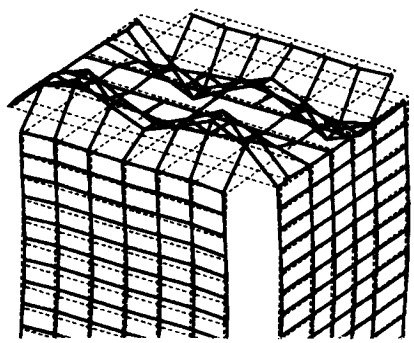

(3) $3.72 \mathrm{~Hz}$

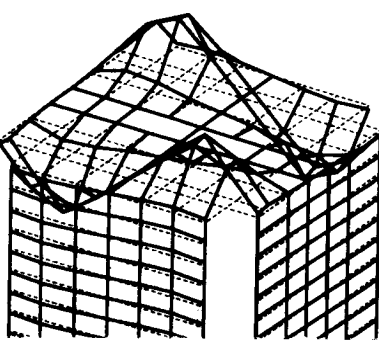

(4) $3.73 \mathrm{~Hz}$

図12 立体解析モデルによる固有振動モード

要素でモデル化している。また、耐震壁はブレース置換している。節 点は床振動を考虑できるように大梁上にも設け、質量は集中質量とし て各節点に与えている。ただし、質量については設計時にはやや大き めの積載荷重が設定されていたため、本解析では 1 次固有振動数が微 動結果と一致するように修正した。また、実構造物ではねじれモード が現れるが、本解析では考虑しなかった。基礎は固定とした。水平方 向には剛床仮定を用いている。解析には当社開発の DAC3N $N^{[13] を}$ 用い た。なお、水平方向の固有振動数は4次モードまでは微動計測結果と 大凡一致した。図 12 に上下方向に関する固有振動数、振動モード図 を、紙面の都合上 $3.5 \mathrm{HZ} \sim 4.0 \mathrm{~Hz}$ 間の 4 つについて示す。実線がモー ド形、破線が建物の原型を表す。図中には各振動モードに対応した図 9の結果を併せて示してある。振動モードは、(1) から（3）のモード については微動計測結果とおおよそ一致した結果が得られた。ただ し、(4)のモードについては、微動計測結果からは明確に捉えられな かった。これはおそらく、図7の○印のピークに対応するものであろ う。また逆に、微動計測で得られた(5)のモードを解析では捉えること ができなかった。一方、固有振動数については(1)、(2)については大凡 一致したが、それよりも高い振動数のモード（3)、(4)、(6) について は微動計測結果よりも低い值となった。立体解析モデルにおいて、(5) のモードが得られなかったことや固有振動数のずれ等の問題を解決す るには、床振動に大きく寄与すると考えられる床版や小梁の剛性と軸 伸緶モードに寄与する間仕切り壁や外壁などの雑壁を適切にモデル化 することが必要となろう。

\section{4. まとめ}

上下方向の振動性状に関するデータの蓄積と、上下応答解析用簡易 モデルの開発を目的として、某鉄骨高層建物において上下方向を中心 とした常時微動の水平・上下同時計測を行った。本報告では、上下応 答解析用簡易モデルの開発の前段階として、この微動計測結果に基づ いて鉄骨高層建物の上下方向の振動特性(振動モードとその卓越振動 数)についての詳細な検討と、その検討結果を検証するための同建物 で得られている地震観測記録を用いた検討と3次元立体解析モデルに よる検討も併せて行った。その結果、今回対象とした建物の上下方向
の振動性状に関して次の点が明らかとなった。(1) 上下方向の振動性 状に関する有用なデータが蓄積できた。(2) 上下方向の振動では、軸 伸縮モード、梁の曲げのモード、あるいはその連成、さらには水平方 向との連成と、多様な振動モードを示し、かつそれらの複数が近接し て現れる。（3）上下方向の振動モード（本報告では $3.9 \mathrm{~Hz}$ ）により水 平方向にピークが生じる場合がある。（4）高次（今回の検討では $4 \mathrm{~Hz}$ 以上）のモードを解析モデルで捉えるためには、床版や小梁、雑壁ま での適切なモデル化か、新たな解析モデルを検討する必要がある。た だし、(4)についてはこれらの高次のモードが地震時の建物応答に与 える影響の程度等をはじめに検討することが必要となろう。

謝辞：本報告で対象とした微動計測にあたっては、ビル管理事務所、 清水建設（株）技術研究所の多くの方々に多大なる御協力を頂きまし た。また、本報告に作成にあたっては、清水建設（株）和泉研究室の 林康裕氏に貴重な御意見を頂きました。ここに感謝の意を表します。

\section{参考文献}

[1] 田中国彦 他:地震観測記録に基づく高層建物の上下方向の応答 性状、大成建設技術研究所報、第 27 号、1994、pp.123-128

[2] 高崎芳夫 他: 地震観測に基づく鉄骨高層建物の振動性状、日本 建築学会大会学術講演梗概集、1994 年 9月、pp.665-666

[3] 小出敏弘 他:大スパンラーメン架構を有する高層建物の振動性 状、間組研究年報、1986 年、pp.219-226

[4] 平澤光春 他: 建物内の上下動の增幅特性、多次元入力地震動と 構造物多次元挙動に関するシンボジウム、1993 年 3 月、pp.43-50 [5] 斎藤知生 他：地震観測による鉄骨高層建物の振動特性の同定、 日本建築学会大会学術講演梗概集、1994 年 9 月、pp.673-674

[6] 佐武直紀 他：水平・上下動同時測定による高層建物の振動特性 評価、日本建築学会関東支部研究報告集、1995 年

[7] 森田高市、神田順：常時微動による減衰定数評価手法に関する考 察、構造工学論文集、1996 年 3 月、pp.553-560

[8] 益永英治 他: 複数の手法による常時微動時の減衰評価法、日本 建築学会大会学術講演梗概集、1996 年 9月、pp.987-988

[9] 寺坂康成 他：建物の隇衰評価におけるRD法の適用について、 日本建築学会大会学術講演梗概集、1996 年 9月、pp.991-992

[10] 横田治彦 他: 振動試験および地震観測データに基づく鉄骨造 高層建物の減衰性状、日本建築学会構造系論文報告集、1993 年11月、 pp.77-84

[11] 藤原悌三、喻 徳明:立体構造物の上下地震応答と耐震設計、日 本建築学会構造系論文報告集、第 449 号、1993 年7月、pp93-102

[12] 日本建築学会：建築物の耐震設計資料、丸善、1981年

[13] 渡辺宏一 他: 三次元非線形振動解析システムDAC3Nの開発、 第 11 回情報システム利用技術シンポジウム、1989 年,pp181-186

[1997年 6 月20日原稿受理 1997 年 9 月 1 日採用決定］ 